\title{
Microwave Assisted Synthesis and Evaluation of Toxicity and Antioxidant Activity of Pyrazoline Derivatives
}

\author{
Jasril, Hilwan Yuda Teruna, Aisyah, Nurlaili, and Rudi Hendra ${ }^{*}$ \\ Department of Chemistry, University of Riau, Kampus Binawidya KM 12.5 Simpang Baru Pekanbaru, 28293, Indonesia
}

*Corresponding author:

email: rudi.hendra@lecturer.unri.ac.id

Received: March 25, 2018

Accepted: January 21, 2019

DOI: $10.22146 / \mathrm{ijc} .34285$
Abstract: Four pyrazoline analogues, 3-(4-methoxyphenyl)-5-naphthalene-1-yl-1phenyl-4,5-dihydro-pyrazole (3), 3-(4-methoxyphenyl)-5-naphthalene-1-yl-4,5-dihydro -1H-pyrazole (4), 3-(2-methoxyphenyl)-5-naphthalene-1-yl-1-phenyl-4,5-dihydropyrazole (5) and 3-(2-methoxyphenyl)-5-naphthalene-1-yl-4,5-dihydro-1H-pyrazole (6) were synthesized via intermolecular cyclization between substituted chalcones and hydrazine derivatives. The compounds were synthesized in two steps. In the first step, the chalcones were synthesized by Claisen-Schmidt reaction. In the second step, they were cyclized with some hydrazine derivatives to form pyrazolines by using glacial acetic acid as a catalyst and assisted by microwave irradiation. The toxicity analysis showed that compound 1 and 2 were toxic with $L_{50}$ values of 11.47 and $0.97 \mu \mathrm{g} / \mathrm{mL}$, respectively. Furthermore, only compound 6 showed high antioxidant activity by using DPPH with an $\mathrm{IC}_{50}$ value of $4.47 \mu \mathrm{g} / \mathrm{mL}$.

Keywords: microwave-assisted synthesis; chalcone; pyrazoline, toxicity; antioxidant activity

\section{- INTRODUCTION}

Heterocyclic nitrogenous compounds and their fused analogs represent an important class of heterocyclic compounds. They exist in numerous natural products, display a wide range of biological and pharmaceutical activities [1]. Pyrazolines are well known, and important nitrogen-containing five-membered heterocyclic compounds and various methods have been published for their synthesis. Pyrazolines constitute an interesting class of heterocycles due to their synthetic versatility and effective biological activities such as antibacterial [6], antimalarial [2], anticancer [3], antioxidant [4], antiinflammatory [5-6], antitumors [7], analgesic [6], antitrypanosome[2], antimicrobial [1,8-9], antitubercular [10], antiviral [11], antidepressant [12-13], anticonvulsant [5], antiamoebic [14-15].

There are various methods for synthesizing pyrazoline, and the presence of these core in any molecule plays a key role in enhancing the activity. The phenyl ring containing halogen and methoxy groups have shown significant biological activities [16]. An especially common procedure is based on the reaction of $\alpha, \beta$ unsaturated aldehydes and ketones with hydrazines. Such a history prompted us to review the synthesis of pyrazolines as an important need which can possess biological and medicinal properties. Therefore, it is necessary to synthesize those compounds in order to obtain pyrazolines by using chalcones as intermediates compound substituted by the methoxy group.

In general, the synthesis of pyrazolines is carried out in 2 stages. The first stage is the synthesis of chalcone with Claisen-Schmidt condensation reaction using aldehyde and ketone derivatives as the starting material under acid or alkaline conditions. The second stage, reacting synthesized chalcone compounds with hydrazine derivatives such as phenylhydrazine and hydrazine hydrate form pyrazolines. Synthesis of pyrazolines can be carried out using acid or alkaline catalysts with heating, stirring, and radiation using microwaves [14,17]. However, in recent years, the use of microwave energy in organic reactions is well-known because it is safer, greener, faster and produces more products than conventional methods. In this report, the 
synthesis of pyrazolines derivates was conducted with microwave assisted and their antioxidant activity.

\section{- EXPERIMENTAL SECTION}

\section{Materials}

The materials used in this study were 1naphthaldehyde (Merck), 2-Methoxyacetophenone (Merck), 4-Methoxyacetophenone (Merck), phenylhydrazine (Merck), hydrazine hydrate (Merck), glacial acetic acid (Merck), ethyl acetate, $n$-hexane, ethanol, methanol, dichloromethane, chloroform, sodium hydroxide $(\mathrm{NaOH})$, hydrochloric acid $(\mathrm{HCl})$, dimethyl sulfoxide (DMSO), TLC plate $\mathrm{GF}_{254}$, Artemia salina Leach, diphenylpicrylhydrazyl (DPPH).

\section{Instrumentation}

The instruments used for characterization were Fourier Transform Infrared (FTIR) spectrophotometer Shimadzu Prestige-21. HPLC (Shimadzu LC Solution), ${ }^{1} \mathrm{H}-\mathrm{NMR}$ spectrometer (JEOL JNM ECA-500 MHz), ${ }^{13} \mathrm{C}-$ NMR spectrometer (JEOL JNM ECA-125 MHz), UVvisible spectrophotometer (Genesys 10S UV-VIS v4.002 2L9N175013), and mass spectrometer (TOF MS). The tools used in this study were set of distillation apparatus, analytical balance, ultrasonic $\left(\mathrm{Ney}^{\odot}\right)$, microwave oven (Samsung ME109F), vacuum pump, Buchner funnel, thermometer, a Fisher-Johns melting point apparatus, UV lamp 254 and $366 \mathrm{~nm}$ (UVL-56 model).

\section{Procedure}

\section{Synthesis of (E)-1-(4-methoxyphenyl)-3-(naphthalene- 1-yl)prop-2-en-1-one (1)}

4-Methoxy acetophenone (5 $\mathrm{mmol})$, 1naphthaldehyde $(5 \mathrm{mmol})$ and $5 \mathrm{~mL}$ of $\mathrm{KOH} 3 \mathrm{~N}(0.3 \mathrm{~mol})$ were dissolved in absolute ethanol $(7.5 \mathrm{~mL})$ in the round bottom flask. The mixture was irradiated by using microwave for $1 \mathrm{~min}$ at $180 \mathrm{~W}$ and monitored by using TLC and neutralized by adding $\mathrm{HCl} 3 \mathrm{~N}(5 \mathrm{~mL})$. The product was then filtered and washed with cold n-hexane followed by cold $\mathrm{H}_{2} \mathrm{O}$.

Chalcone (E)-1-(4-methoxyphenyl)-3-(naphthalen-1yl)prop-2-en-1-one (1). Molecular formula $\mathrm{C}_{20} \mathrm{H}_{16} \mathrm{O}_{2}$, $\mathrm{m} / \mathrm{z} 289.1235[\mathrm{M}+\mathrm{H}]^{+}$, yield $97.19 \%$, m.p. $83-85^{\circ} \mathrm{C}$, UV $(\mathrm{nm}, \varepsilon): 221.0\left(\varepsilon=2879.84 \mathrm{~L} \mathrm{~mol}^{-1} \mathrm{~cm}^{-1}\right)$, and $351.0(\varepsilon=$
$325.44 \mathrm{~L} \mathrm{~mol}^{-1} \mathrm{~cm}^{-1}$ ), FT-IR (KBr disc) : $3058 \mathrm{~cm}^{-1}$ (aromatic C-H); $3011 \mathrm{~cm}^{-1}$ (alkene C-H); 2839 and 2957 $\mathrm{cm}^{-1}$ (aliphatic C-H), $1654 \mathrm{~cm}^{-1}(\mathrm{C}=\mathrm{O}) ; 1602$ and 1467 $\mathrm{cm}^{-1}(\mathrm{C}=\mathrm{C})$ and $1255 \mathrm{~cm}^{-1}(\mathrm{C}-\mathrm{O}),{ }^{1} \mathrm{H}-\mathrm{NMR}\left(\mathrm{CDCl}_{3}, 500\right.$ $\mathrm{MHz}): 8.67\left(\mathrm{~d}, J \mathrm{H}_{\beta}=15.4 \mathrm{~Hz}, 1 \mathrm{H}, \mathrm{H}_{\beta}\right) ; 7.65\left(\mathrm{~d}, J \mathrm{H}_{\alpha}=\right.$ 15.4 Hz, $1 \mathrm{H}, \mathrm{H}_{\mathrm{a}}$ ); 8,28 (dd, $J=8,65$ and $J=2 \mathrm{~Hz}, 1 \mathrm{H}, \mathrm{H}-$ 4) ; $8,10(\mathrm{dd}, J=9$ and $J=2 \mathrm{~Hz}, 2 \mathrm{H}, \mathrm{H}-2,6) ; 7,94(\mathrm{~m}, 3 \mathrm{H}$, H-5', 2', 8'); 7.59 (m, 1H, H-3'); 7.53 (m, 2H, H-6', 7'); $7.00(\mathrm{dd}, J=9$ and $J=2,1 \mathrm{~Hz}, 2 \mathrm{H}, \mathrm{H}-3,5) ; 3.91(\mathrm{~s}, 3 \mathrm{H}$, $\left.\mathrm{OCH}_{3}\right) .{ }^{13} \mathrm{C}-\mathrm{NMR}\left(\mathrm{CDCl}_{3}, 125 \mathrm{MHz}\right): 188.5(1 \mathrm{C}, \mathrm{C}=\mathrm{O})$; 163.5 (1C,C-4); 140.9 (1C, C- $\beta$ ); 133.7 (1C, C-1'); 132.6 (1C, C-9'); 131.8 (1C, C-10'); 131.0 (1C, C-1); 130.9 (2C, C-2, C-6); 130.6 (1C, C-5'); 128.7 (1C, C-4'); 126.9 (1C, C-7'); 126.3 (1C, C-6'); 125.5 (1C,C-3'); 125.0 (1C, C-8'); 124.6 (1C, C-2'); 123.6 (1C, C- $\alpha$ ); 113.9 (2C, C-3, C-5), $55.5\left(1 \mathrm{C}, \mathrm{OCH}_{3}\right)$.

\section{Synthesis of (E)-1-(2-methoxyphenyl)-3- (naphthalene-1-yl)prop-2-en-1-one (2)}

2-Methoxyacetophenone (5 $\mathrm{mmol}), \quad 1$ naphthaldehyde $(5 \mathrm{mmol})$ and $5 \mathrm{~mL}$ of $\mathrm{NaOH} 1 \mathrm{~N}(0.01$ $\mathrm{mol}$ ) were dissolved in absolute ethanol $(7.5 \mathrm{~mL})$ in the round bottom flask. The mixture was irradiated by using microwave for $2 \mathrm{~min}$ at $180 \mathrm{~W}$ and monitored by using TLC and neutralized by adding $\mathrm{HCl} 3 \mathrm{~N}(5 \mathrm{~mL})$. The product was filtered and washed with cold $n$-hexane followed by cold $\mathrm{H}_{2} \mathrm{O}$. Then, it was allowed to air-dry, and the purity was determined by using TLC.

Chalcone (E)-1-(2-methoxyphenyl)-3-(naphthalen1-yl)prop-2-en-1-one (2). Molecular formula $\mathrm{C}_{20} \mathrm{H}_{16} \mathrm{O}_{2}$, $\mathrm{m} / \mathrm{z} 289[\mathrm{M}+\mathrm{H}]^{+}, 1227$, yield $96.29 \%$, m.p. $79-81{ }^{\circ} \mathrm{C}$, UV $(\mathrm{nm}, \varepsilon): 219.0\left(\varepsilon=20102.41 \mathrm{~L} \mathrm{~mol}^{-1} \mathrm{~cm}^{-1}\right), 260.0(\varepsilon=6624$ $\left.\mathrm{L} \mathrm{mol}^{-1} \mathrm{~cm}^{-1}\right)$ and $349.0\left(\varepsilon=6422 \mathrm{~L} \mathrm{~mol}^{-1} \mathrm{~cm}^{-1}\right)$, FT-IR (KBr disc): $3075 \mathrm{~cm}^{-1}(\mathrm{C}-\mathrm{H}) ; 2834 \mathrm{~cm}^{-1}(\mathrm{C}-\mathrm{H}) ; 1653 \mathrm{~cm}^{-}$ ${ }^{1}(\mathrm{C}=\mathrm{O}) ; 1600 \mathrm{~cm}^{-1}(\mathrm{C}=\mathrm{C}) ; 1573 \mathrm{~cm}^{-1}(\mathrm{C}=\mathrm{C}) ; 1277 \mathrm{~cm}^{-1}$ (C-O), ${ }^{1} \mathrm{H}-\mathrm{NMR}\left(\mathrm{CDCl}_{3}, 500 \mathrm{MHz}\right): 8.51\left(\mathrm{~d}, J \mathrm{H}_{\beta}=15\right.$ $\left.\mathrm{Hz}, 1 \mathrm{H}, \mathrm{H}_{\beta}\right) ; 8.25$ (d, J = $8.41 \mathrm{~Hz}, 1 \mathrm{H}, \mathrm{H}-2$ ) $) 7.89$ (m, $3 \mathrm{H}$, H-4', 8', 5'); 7.73 (dd, $J=7.59 \mathrm{~Hz}, 1 \mathrm{H}, \mathrm{H}-6) ; 7.54$ (m, 4H, H-3', 7', 6', 4); $7.50\left(\mathrm{~d}, J_{\mathrm{Ha}}=15 \mathrm{~Hz}, 1 \mathrm{H}, \mathrm{H}_{\alpha}\right) ; 7.09$ (td, $J=$ $7.49 \mathrm{~Hz}, 1 \mathrm{H}, \mathrm{H}-5) ; 7.04$ (d, J= $8.53 \mathrm{~Hz}, 1 \mathrm{H}, \mathrm{H}-3) ; 3.94$ (s, $\left.3 \mathrm{H}, \mathrm{OCH}_{3}\right),{ }^{13} \mathrm{C}-\mathrm{NMR}\left(\mathrm{CDCl}_{3}, 125 \mathrm{MHz}\right): 192.7(1 \mathrm{C}$, $\mathrm{C}=\mathrm{O}) ; 158.2$ (1C, C-2); 139.9 (1C, C- $\alpha$ ); 133.7 (1C, C- $\beta$ ); 133.0 (1C, C-9'); 132.5 (1C, C-1'); 131.7 (1C, C-4); 130.5 (1C, C-1); 130.4 (1C, C-10'); 129.6 (1C, C-4'); 129.2 (1C, 
C-6’); 128.7 (1C, C-7'); 126.8 (1C, C-5'); 126.2 (1C, C-6); 125.4 (1C, C-8'); 125.1 (1C, C-3'); 123.6 (1C, C-5); 120.8 (1C, C-2'); 111.6 (1C, C-3); 55.7 (1C, C-OCH ${ }_{3}$ ).

\section{Synthesis of pyrazolines}

Chalcones $(1 \mathrm{mmol})$ were dissolved in $10 \mathrm{~mL}$ ethanol. Then, drops of glacial acetic acid and hydrazine derivative $(10 \mathrm{mmol})$ were added to the solution respectively. The mixture was irradiated by using microwaves for 2-4 min at $180 \mathrm{~W}$ and monitored by TLC. Then, the compounds purifications were conducted using TLC and HPLC. The TLC was carried out by using silica gel plate and hexane:ethyl acetate $(3: 7 \mathrm{v} / \mathrm{v})$ as eluents and the results were observed under UV light (254 and 366 $\mathrm{nm})$. Furthermore, the purification analysis was done by using RP-HPLC with OCD column, water: acetonitrile in a gradient system for $30 \mathrm{~min}$.

Synthesis of 3-(4-methoxy-phenyl)-5-naphtalen-1yl-1-phenyl-4,5-dihydro-pyrazole (3 ). Molecular formula $\mathrm{C}_{26} \mathrm{H}_{22} \mathrm{~N}_{2} \mathrm{O}, \mathrm{m} / \mathrm{z} 379.1818[\mathrm{M}+\mathrm{H}]^{+}$, yield $32.33 \%$, m.p. $137-139^{\circ} \mathrm{C}$, UV $(\mathrm{nm}, \varepsilon): 224.0\left(\varepsilon=33793 \mathrm{~L} \mathrm{~mol}^{-1} \mathrm{~cm}^{-}\right.$ $\left.{ }^{1}\right), 261.0\left(\varepsilon=9261 \mathrm{~L} \mathrm{~mol}^{-1} \mathrm{~cm}^{-1}\right)$, FT-IR (KBr): $3044 \mathrm{~cm}^{-1}$ (aromatic C-H); 2931 and $2833 \mathrm{~cm}^{-1}$ (aliphatic C-H); 1595 $\mathrm{cm}^{-1}(\mathrm{C}=\mathrm{N}) ; 1497 \mathrm{~cm}^{-1}(\mathrm{C}=\mathrm{C}) ; 1388 \mathrm{~cm}^{-1}(\mathrm{C}-\mathrm{N}) ; 1249(\mathrm{C}-$ O). ${ }^{1} \mathrm{H}-\mathrm{NMR}\left(\mathrm{CDCl}_{3}, 500 \mathrm{MHz}\right): 8.11(\mathrm{~d}, J=8 \mathrm{~Hz}, 1 \mathrm{H}, \mathrm{H}-$ 8'”); 7.96 (d, $J=10 \mathrm{~Hz}, 1 \mathrm{H}, \mathrm{H}-5$ '”); 7.80 (d, $J=8 \mathrm{~Hz}, 1 \mathrm{H}$, H-4"'); 7.68 (dd, $J=8,5$ and $2 \mathrm{~Hz}, 2 \mathrm{H}, \mathrm{H}-2$ ", 6 "), 7.60 (m, 2H, H-6"', 7'”); 7.46 (d, $J=7,5 \mathrm{~Hz}, 1 \mathrm{H}, \mathrm{H}-2$ "'); 7.39 (t, $J=$ $7,5 \mathrm{~Hz}, 1 \mathrm{H}, \mathrm{H}-3$ "'); 7.18 (m, 2H, H-3", 5"); 7.06 (d, $J=8$ $\mathrm{Hz}$ ), 2H, H-2',6'; 6.92 (dd, $J=8.5$ and $1.2 \mathrm{~Hz}, 2 \mathrm{H}, \mathrm{H}-3^{\prime \prime}$, 5"); 6.79 (t, $J=7,5 \mathrm{~Hz}, 1 \mathrm{H}, \mathrm{H}-4$ '); 5.91 (broad, $1 \mathrm{H}, \mathrm{Hx}$ ); $4.04\left(\mathrm{dd}, J_{\mathrm{ba}}=15.25\right.$ and $\left.J_{\mathrm{bx}}=12.44 \mathrm{~Hz}, 1 \mathrm{H}, \mathrm{Hb}\right) ; 3.84(\mathrm{~s}$, $\left.3 \mathrm{H} / \mathrm{OCH}_{3}\right)$ and $3.14\left(\mathrm{~d}, J_{\mathrm{ab}}=15.25 \mathrm{~Hz}, 1 \mathrm{H}, \mathrm{Ha}\right) \cdot{ }^{13} \mathrm{C}-\mathrm{NMR}$ $\left(\mathrm{CDCl}_{3}, 125 \mathrm{MHz}\right): 160.1$ (1C, C-4");147.3 (1C, C-3); 145.2 (1C, C-1'); 136.8 (1C, C-1"'); 134.4 (1C, C-10"'); 129.9 (1C, C-9"'); 129.3 (1C, C-5"'); 128.9 (2C, C-3' and C-5'); 128.0 (1C, C-4"'); 127.2 (2C, C-2" and C-6"); 126.4 (1C, C-6”"); 126.0 (1C, C-3"'); 125.7 (2C, C-2"' and C7"'); 125.5 (1C, C-1'); 126.0 (1C, C-8'”); 118.8 (1C, C-4'); 114.0 (2C, C-3' and C-5'); 113.2 (2C, C-2' and C-6'); 61.2 (1C, $\left.\mathrm{C}-5^{\prime \prime \prime}\right) ; 55.4\left(1 \mathrm{C}, \mathrm{OCH}_{3}\right)$ and $43.9(1 \mathrm{C}, \mathrm{C}-4)$.

Synthesis of 3-(4-methoxyphenyl)-5-(naphthalen-1yl)-4,5-dihydro-1H-pyrazole(4). Molecular formula $\mathrm{C}_{20} \mathrm{H}_{18} \mathrm{~N}_{2} \mathrm{O}, \mathrm{m} / \mathrm{z} 303.1497[\mathrm{M}+\mathrm{H}]^{+}$, yield 67.68\%, m.p. 79- $81^{\circ} \mathrm{C}$, UV $(\mathrm{nm}, \varepsilon): 223.0\left(\varepsilon=23284 \mathrm{~L} \mathrm{~mol}^{-1} \mathrm{~cm}^{-1}\right), 284.0$ $\left(\varepsilon=6584 \mathrm{~L} \mathrm{~mol}^{-1} \mathrm{~cm}^{-1}\right)$, FT-IR (KBr): $3044 \mathrm{~cm}^{-1}$ (aromatic C-H); 2931 and $2833 \mathrm{~cm}^{-1}$ (aliphatic C-H); $1595(\mathrm{C}=\mathrm{N}) ; 1497 \mathrm{~cm}^{-1}(\mathrm{C}=\mathrm{C}) ; 1388 \mathrm{~cm}^{-1}(\mathrm{C}-\mathrm{N}) ; 1249$ $\mathrm{cm}^{-1}(\mathrm{C}-\mathrm{O}) .{ }^{1} \mathrm{H}-\mathrm{NMR}$ (DMSO, $\left.500 \mathrm{MHz}\right): 8.16$ (d, $J=8,5$ $\mathrm{Hz}, 1 \mathrm{H}, \mathrm{H}-8$ ”); 7,95 (d, J = 7,5 Hz, 1H, H-5”); 7.83 (d, J $=8 \mathrm{~Hz}, 1 \mathrm{H}, \mathrm{H}-4$ "); 7.70 (d, $J=7 \mathrm{~Hz}, 1 \mathrm{H}, \mathrm{H}-2$ "); 7.56 (m, 2H, H-2', 6'); 7.54 (m, 2H, H-6", 7'); 7.48 (t, $J=7,5 \mathrm{~Hz}$, $\left.1 \mathrm{H}, \mathrm{H}-3^{\prime \prime}\right) ; 6.92$ (d, J = 8,5 Hz, 2H, H-3', ' '); 5.54 (t, Jax = $\left.J_{\mathrm{bx}}=10.5 \mathrm{~Hz}, 1 \mathrm{H}, \mathrm{Hx}\right) ; 3.75\left(\mathrm{~s}, 3 \mathrm{H}, \mathrm{CH}_{3}\right) ; 3.71\left(\mathrm{dd}, J_{\mathrm{ba}}=\right.$ 11 and $\left.J_{\mathrm{bx}}=5 \mathrm{~Hz}, 1 \mathrm{H}, \mathrm{Hb}\right)$ and $2.76\left(\mathrm{dd}, J_{\mathrm{ab}}=11\right.$ and $J_{\mathrm{ax}}$ $=5.5 \mathrm{~Hz}, 1 \mathrm{H}, \mathrm{Ha}) \cdot{ }^{13} \mathrm{C}-\mathrm{NMR}(\mathrm{DMSO}, 125 \mathrm{MHz}): 159.7$ (1C, C-4'); 149.0 (1C,C-3); 139.3 (1C, C-1"); 134.0 (1C, C-10"); 131.0 (1C, C-9"); 129.1 (1C, C-5"); 127.8 (1C, C4"); 127.4 (2C, C-2' and C-6'); 126.6 (1C, C-7”); 123.6 (C-2'); 126.1 (1C, C-6”); 126.0 (1C, C-3"); 124.1 (1C, C8"); 123.6 (1C, C-2"); 114.4 (2C, C-3' and C-5'); 60.7 (1C, $\mathrm{C}-5) ; 55.6\left(1 \mathrm{C}, \mathrm{CH}_{3}\right)$ and $41.1(1 \mathrm{C}, \mathrm{C}-4)$.

Synthesis of 3-(2-methoxyphenyl)-5-(naphthalen1-yl)-1-phenyl-4,5-dihydropyrazole (5). Molecular formula $\mathrm{C}_{26} \mathrm{H}_{22} \mathrm{~N}_{2} \mathrm{O}, \mathrm{m} / \mathrm{z} 379.1815[\mathrm{M}+\mathrm{H}]^{+}$, yield 40.95\%, m.p. $178-179^{\circ} \mathrm{C}$, UV (nm, $\left.\varepsilon\right): 221.0(\varepsilon=45738.05$ $\left.\mathrm{L} \mathrm{mol}^{-1} \mathrm{~cm}^{-1}\right), 294.0\left(\varepsilon=8694.01 \mathrm{~L} \mathrm{~mol}^{-1} \mathrm{~cm}^{-1}\right)$, FT-IR $(\mathrm{KBr}): 3063 \mathrm{~cm}^{-1}(\mathrm{C}-\mathrm{H}) ; 3009 \mathrm{~cm}^{-1}(\mathrm{C}-\mathrm{H}) ; 1596 \mathrm{~cm}^{-1}$ $(\mathrm{C}=\mathrm{N}) ; 1501 \mathrm{~cm}^{-1}(\mathrm{C}=\mathrm{C}) ; 1325 \mathrm{~cm}^{-1}(\mathrm{C}-\mathrm{N}) ; 1247(\mathrm{C}-\mathrm{O})$, ${ }^{1} \mathrm{H}-\mathrm{NMR}\left(\mathrm{CDCl}_{3}, 500 \mathrm{MHz}\right): 8.16(\mathrm{~d}, J=8.42 \mathrm{~Hz}, 1 \mathrm{H}, \mathrm{H}-$ 8"'); 8.08 (dd, $J=7.76 \mathrm{~Hz}, 1 \mathrm{H}, \mathrm{H}-6$ "); 7.96 (d, $J=7.95$ Hz, 1H, H-5”'); 7.81 (d, J = 8.09 Hz, 1H, H-2"'); 7.65 (t, $J=7.39 \mathrm{~Hz}, 1 \mathrm{H}, \mathrm{H}-7$ '”); 7.59 (t, $J=7.39 \mathrm{~Hz}, 1 \mathrm{H}, \mathrm{H}-6$ "'); $7.48(\mathrm{~d}, J=7.07 \mathrm{~Hz}, 1 \mathrm{H}, \mathrm{H}-4$ '”); $7.41(\mathrm{t}, J=7.67 \mathrm{~Hz}, 1 \mathrm{H}$, H-3'”); 7.32 (t, J = 8.37 Hz, 1H); 7.18 (m, 2H, H-3', 5'); 7.07 (m, 3H, H-2', 6', 5”); 6.90 (d, J= 8.09 Hz, 1H, H-3”); $6.80\left(\mathrm{t}, J=7.28 \mathrm{~Hz}, 1 \mathrm{H}, \mathrm{H}-4^{\prime}\right) ; 5.91\left(\mathrm{~s}, 1 \mathrm{H}, \mathrm{H}_{\mathrm{x}}\right) ; 4.23$ (dd, $J_{\mathrm{ab}}=17 \mathrm{~Hz}$ and $\left.J_{\mathrm{bx}}=12.5 \mathrm{~Hz}, 1 \mathrm{H}, \mathrm{H}_{\mathrm{b}}\right) ; 3.78\left(\mathrm{~s}, 3 \mathrm{H} / \mathrm{OCH}_{3}\right)$; $3.36\left(\mathrm{~d}, J_{\mathrm{ab}}=17 \mathrm{~Hz}\right.$ and $\left.J_{\mathrm{ax}}=7 \mathrm{~Hz}, 1 \mathrm{H}, \mathrm{H}_{\mathrm{a}}\right){ }^{13} \mathrm{C}-\mathrm{NMR}$ $\left(\mathrm{CDCl}_{3}, 125 \mathrm{MHz}\right)$ : 157.4 (1C, C-2"); 147.2 (1C, C-3); 145.2 (1C, C-1'); 137.2 (1C, C-1"'); 134.3 (1C, C-10"'); 130.0 (1C, C-9"'); 129.9 (1C, C-4"); 129.1 (1C, C-5"'); 128.9 (2C, C-3' and C-5'); 128.8 (1C, C-6"); 127.8 (1C, C-2"'); 126.3 (1C, C-7"'); 126.0 (1C, C-3"'); 125.6 (1C, C-6"'); 123.1 (2C, C-4"' and C-8"'); 121.9 (1C, C-1"); 120.8 (1C, C-5”); 118.8 (1C, C-4'); 113.3 (2C, C-2' and 
C-6'); 111.4 (1C, C-3”); 61.5 (1C, C-5); $55.4\left(1 \mathrm{C}, \mathrm{OCH}_{3}\right)$; 45.8 (1C, C-4).

\section{Synthesis of 3-(2-methoxyphenyl)-5-(naphthalen-1-} yl)-4,5-dihydro-1H-pyrazole (6). Molecular formula $\mathrm{C}_{20} \mathrm{H}_{18} \mathrm{~N}_{2} \mathrm{O}, \mathrm{m} / \mathrm{z} 303.1492[\mathrm{M}+\mathrm{H}]^{+}$, yield 41.62\%, m.p. 88$90^{\circ} \mathrm{C}, \mathrm{UV}(\mathrm{nm}, \varepsilon): 222.0\left(\varepsilon=93621.6 \mathrm{~L} \mathrm{~mol}^{-1} \mathrm{~cm}^{-1}\right), 296.0$ $\left(\varepsilon=14798.2 \mathrm{~L} \mathrm{~mol}^{-1} \mathrm{~cm}^{-1}\right)$, FT-IR (KBr): $3363 \mathrm{~cm}^{-1}(\mathrm{~N}-$ $\mathrm{H}) ; 3048 \mathrm{~cm}^{-1}(\mathrm{C}=\mathrm{H}) ; 3007 \mathrm{~cm}^{-1}(\mathrm{C}-\mathrm{H}) ; 1596(\mathrm{C}=\mathrm{N}) ; 1509$ $\mathrm{cm}^{-1}(\mathrm{C}=\mathrm{C}) ; 1336 \mathrm{~cm}^{-1}(\mathrm{C}-\mathrm{N}) ; 1239 \mathrm{~cm}^{-1}(\mathrm{O}-\mathrm{C}),{ }^{1} \mathrm{H}-\mathrm{NMR}$ (DMSO, $500 \mathrm{MHz}): 8.14$ (d, $\left.J=8.11 \mathrm{~Hz}, 1 \mathrm{H}, \mathrm{H}-8^{\prime \prime}\right) ; 7.95$ (d, $J=7.41 \mathrm{~Hz}, 1 \mathrm{H}, \mathrm{H}-5$ "); 7.83 (d, $J=8.19 \mathrm{~Hz}, 1 \mathrm{H}, \mathrm{H}-4$ "); 7.71 (dd, $J=7.68 \mathrm{~Hz}, 2 \mathrm{H}, \mathrm{H}-2$ ", 6); 7.53 (m, 4H, H-7", 6", 3', 4'); 7.29 (m, 1H, H-5'); $7.02(\mathrm{dd}, J=8.21 \mathrm{~Hz}, 1 \mathrm{H}, \mathrm{H}-1)$; 6.09 (m, 1H, H-3"); 5.53 (dd, $J=12.5 \mathrm{~Hz}, 1 \mathrm{H}, \mathrm{H}_{\mathrm{x}}$ ); 3.75 $\left(\mathrm{dd}, J_{\mathrm{ba}}=17 \mathrm{~Hz}\right.$ and $\left.J_{\mathrm{bx}}=12.5 \mathrm{~Hz}, 1 \mathrm{H}, \mathrm{H}_{\beta}\right) ; 2.90\left(\mathrm{dd}, J_{\mathrm{ab}}=\right.$ $17 \mathrm{~Hz}$ and $\left.J_{\mathrm{ax}}=7 \mathrm{~Hz}, 1 \mathrm{H}, \mathrm{H}_{\alpha}\right) ; 3.72\left(\mathrm{~s}, 3 \mathrm{H}, \mathrm{OCH}_{3}\right),{ }^{13} \mathrm{C}-$ NMR (DMSO, $125 \mathrm{MHz}$ ) : 157.3 (1C, C-2'); 148.1 (1C, C3);139.3 (1C, C-1"); 133.9 (1C, C-10"); 130.9 (1C, C-9"); 130.0 (1C, C-5'); 129.0 (1C, C-5”); 128.4 (1C, C-2”); 127.7 (1C, C-4"); 126.5 (1C, C-7”); 126.1 (1C, C-6"); 126.0 (1C, C-4'); 124.0 (1C, C-8”); 123.5 (1C, C-6');122.9 (1C, C-1'); 120.9 (1C, C-3”); 112.5 (1C, C-3'); 61.0 (1C, C-5); 55.9 $\left(1 \mathrm{C}, \mathrm{OCH}_{3}\right) ; 44.3(1 \mathrm{C}, \mathrm{C}-4)$.

\section{Toxicity assay}

$\mathrm{LC}_{50}$ was determined by Brine Shrimp Lethality Test (BSLT) method. Mortality percentage of Artemia salina in various concentrations of chalcone and pyrazoline in seawater and 10\% (v/v) DMSO were observed within 24 h. Data obtained were analyzed using probit analysis.

\section{Antioxidant activity}

Samples were prepared with a certain concentration in methanol. Approximately $100 \mu \mathrm{L}$ of the sample was transferred into row A of the microplate (plate consist of A-H rows, each row consists of 12 wells). Two-fold dilutions of the compound were added to the next row until the concentration was $31.25 \mu \mathrm{g} / \mathrm{mL}$. Diphenylpicrylhydrazyl (DPPH) $\quad(1000 \mu \mathrm{g} / \mathrm{mL} \quad$ in methanol) as much as $5 \mu \mathrm{L}$ was added to each well of the sample. The microtiter plate was then vortexed and incubated for $30 \mathrm{~min}$ in the dark room [18]. Then, absorbance was measured, and the total percentage of radical scavenging activity was calculated based on the following formula:

$\%$ Scavenging $=[($ A control $-\mathrm{A}$ sample $) / \mathrm{A}$ control $] \times 100 \%$

\section{- RESULTS AND DISCUSSION}

\section{Synthesis}

Compound 1 and 2 were synthesized by using Claisen-Schmidt condensation reaction and yielded 97.19 and $96.29 \%$, respectively. The synthesis was assisted with microwave irradiation because this technique has advantages such as time efficiency (faster), easy to control, energy saving, and furthermore, it can increase the percentage of yield product, but not in every case [19].

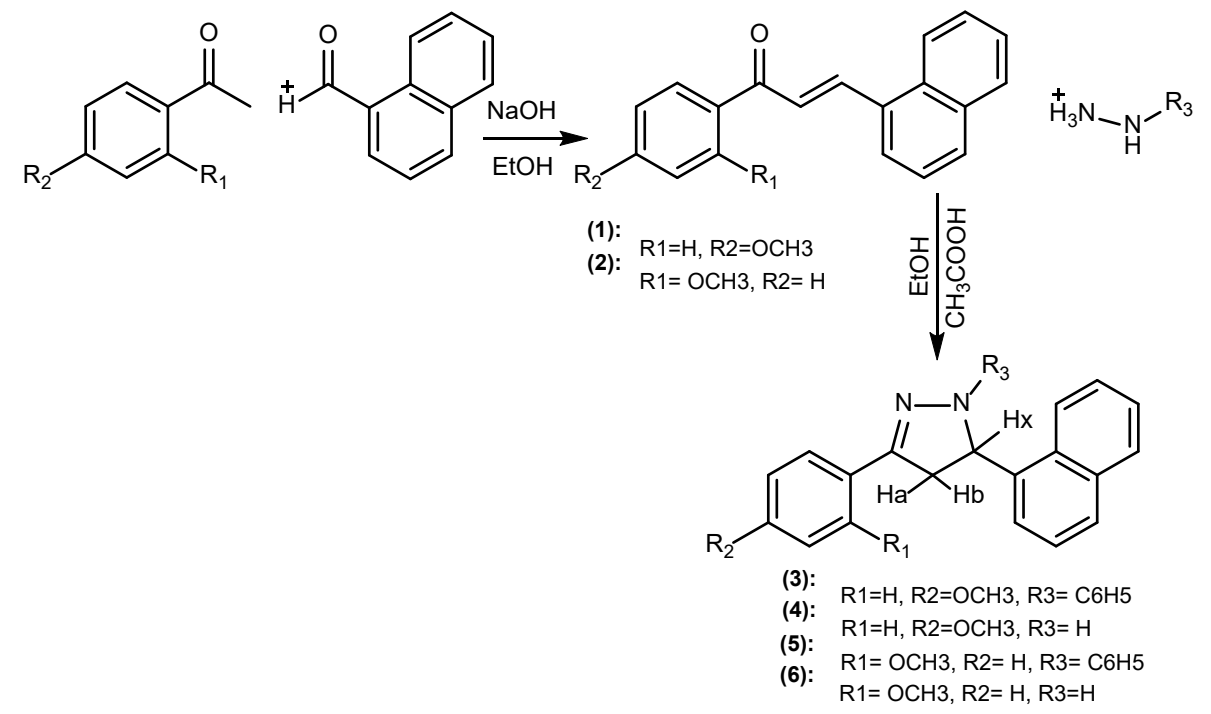

Fig 1. Synthetic pathway of pyrazoline derivatives 
The ${ }^{1} \mathrm{H}-\mathrm{NMR}$ spectra analysis of compound $\mathbf{1}$ and $\mathbf{2}$ showed the characteristics of proton signals for chalcones and also showed the number of protons corresponding to the expected target compounds. From the ${ }^{1} \mathrm{H}-\mathrm{NMR}$ spectra showed $\alpha, \beta$-unsaturated protons resonance at 7.65 and $8.67 \mathrm{ppm}$ for chalcone $\mathbf{1}$ and 7.50 and $8.51 \mathrm{ppm}$ for chalcone 2 with coupling constant $15 \mathrm{~Hz}$ which indicated trans isomer. ${ }^{13} \mathrm{C}$-NMR spectra in compounds $\mathbf{1}$ and 2 show a carbonyl signal from ketone group $(\mathrm{C}=\mathrm{O})$ resonance at 188.5 and $192.7 \mathrm{ppm}$, respectively. In addition, carbon alkene signal $(\mathrm{C}=\mathrm{C})$ which is $\mathrm{C} \alpha$ and $\mathrm{C} \beta$ also appears for compound 1 at 124.6 and $140.9 \mathrm{ppm}$, while compound 2 resonance at 139.9 and $133.7 \mathrm{ppm}$, respectively.

Furthermore, to synthesize compounds 3, 4, 5 and 6, chalcones were reacted with phenylhydrazine and hydrazine hydrate followed by irradiation with microwave using acetic acid as a catalyst. The structure of pyrazolines was established by FTIR, H-NMR, HSQC, and HMBC. In general, FTIR spectra of pyrazoline showed absorption bands $\left(\mathrm{cm}^{-1}\right)$ around 3000 (aliphatic $\mathrm{C}-\mathrm{H}), 1596(\mathrm{C}=\mathrm{N})$ and $1330(\mathrm{C}-\mathrm{N})$ which indicates the formation of pyrazoline rings. ${ }^{1} \mathrm{H}-\mathrm{NMR}$ spectra also showed $\mathrm{ABX}$ system of pyrazoline ring protons, which resonance at $\delta 3.14(\mathrm{~d}, J=15.25 \mathrm{~Hz})$ and $4.04\left(\mathrm{dd}, J_{b a}=\right.$ 15.25 and $J_{b x}=12.44 \mathrm{~Hz}$ ) assigned to $\mathrm{Ha}$ and $\mathrm{Hb}$ in the methylene ring of pyrazoline, respectively. Furthermore, a signal resonance at $\delta 5.0(\mathrm{t}, J=12.40 \mathrm{~Hz}) \mathrm{ppm}$ assigned to $\mathrm{Hx}$ in a pyrazoline ring. The protons of methoxy appeared as singlets around $\delta 3.7$, while protons of phenyl rings appeared around $\delta 7.8 \mathrm{ppm}$.

The HSQC spectra of pyrazoline 3 showed a correlation between proton $\mathrm{Ha}(\delta 3.14)$ and $\mathrm{Hb}(\delta 4.04)$ with carbon C-4"' $(\delta 42.9)$. In addition, there was also a correlation between three protons at $3.84 \mathrm{ppm}\left(\mathrm{OCH}_{3}\right)$ with carbon at $55.4 \mathrm{ppm}\left(4-\mathrm{OCH}_{3}\right)$ indicating the presence of substituents of the $p$-methoxyphenyl group (phenyl ring). Furthermore, HSQC spectra of pyrazoline 4 showed a correlation of $\mathrm{Ha}(\delta 2.76)$ and $\mathrm{Hb}(\delta 3.71)$ protons with carbon $\mathrm{C}-4(\delta 42.1)$. Hx proton $(\delta 5.54)$ correlates with carbon C-5" ( $\delta$ 60.7). In the same manner, ${ }^{1} \mathrm{H}$ NMR and HSQC spectra of 5 showed the presence of pyrazoline ring and $o$-methoxy group in phenyl ring (Fig. 3). Furthermore, from $1 \mathrm{H}$ NMR spectra analysis of $\mathbf{6}$ showed the presence of pyrazoline ring in the same manner with compound 3, 4 and 5. However, the H1 NMR spectra showed a signal resonance at $\delta 7.01(\mathrm{~d}, J=5.0 \mathrm{~Hz})$ assigned to $\mathrm{H}-1$ " (Fig. 3 ) and it was supported by HSQC spectra analysis where there was no correlation with any carbon.

The HMBC spectra for pyrazoline $\mathbf{3}$ show proton and carbon correlation within 2-3 bonds. Both protons namely $\mathrm{Ha}$ and $\mathrm{Hb}$ at $\mathrm{C} 4$ atoms each have a correlation with carbon C-3"' ( 2 bonds) and C-1"' (3 bonds). The HMBC spectra for pyrazoline $\mathbf{4}$ show proton and carbon correlation within 2-3 bonds. Both protons ( $\mathrm{Ha}$ and $\mathrm{Hb}$ ) on C4" atoms each have a correlation with carbon C-3" ( 2 bonds), C5" ( 2 bonds) and C1' (3 bonds). Whereas proton $\mathrm{Hx}$ on $\mathrm{C}-5$ " atoms has a correlation with carbon C-3" ( 3 bonds), carbon C-4" (2 bonds), C-1' (2 bonds), C-2' ( 3 bonds) and C-9' (3 bonds) which indicated that the product was pyrazoline and not the oxidation product pyrazole (Fig. 2). The spectra of HMBC compounds 5 and $\mathbf{6}$ showed a similar pattern from compounds $\mathbf{3}$ and $\mathbf{4}$ it was indicated that the synthesis of the compounds matches with the target molecule. Spectra

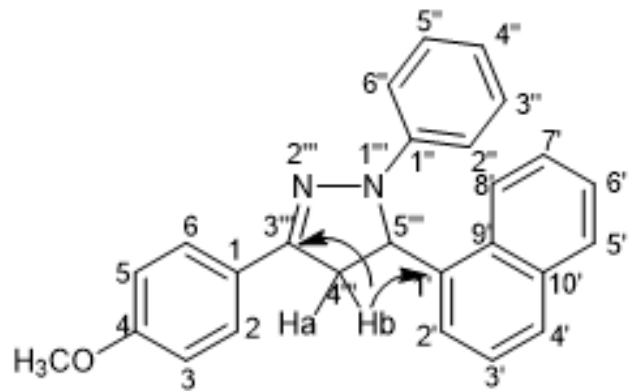

(3)

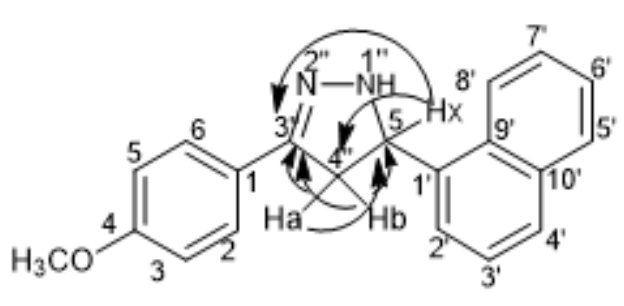

(4)

Fig 2. Important HMBC correlation of pyrazoline ring (3) and (4) 


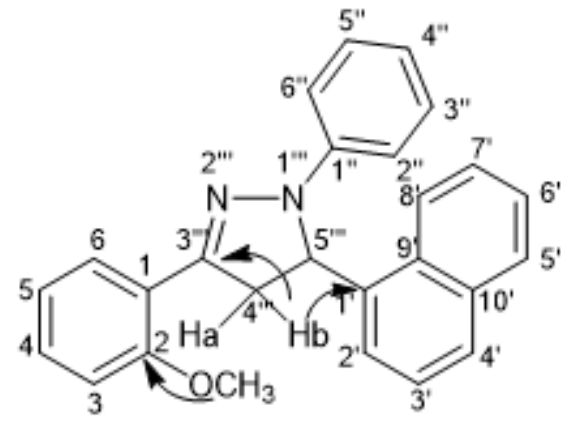

(5)

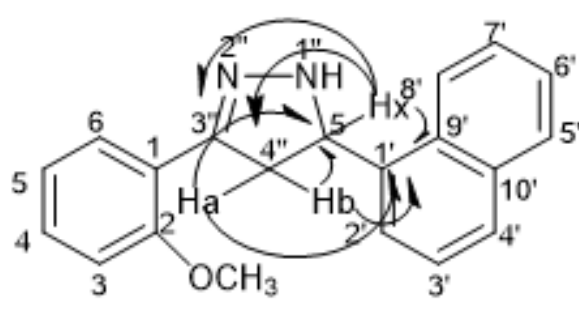

(6)

Fig 3. Important $\mathrm{HMBC}$ correlation of pyrazoline ring (5) and (6)

of $\mathrm{HMBC}$ compounds 5 showed both Ha protons and $\mathrm{Hb}$ on C-4"' atoms each have a correlation with carbon C-3"' ( 2 bonds), C-1"' (3 bonds). Whereas Hx protons on C-5"' atoms do not show correlation with carbon C-4"' (2 bonds). While the HMBC spectra for compound $\mathbf{6}$ show a correlation between protons and carbon spaced 2-3 bonds. Both Ha protons and $\mathrm{Hb}$ on C-4" atoms each have a correlation with carbon C-3" (2 bonds), C-5" (2 bonds) and C-1' ( 3 bonds). While Hx protons on C-5" atoms have a correlation with carbon C-3" (2 bonds), C-4" ( 2 bonds), C-1" (2 bonds), C-9' (3 bonds). The HMBC spectra also showed important correlations as shown in Fig. 3.

The HRMS spectra showed pyrazoline compounds were observed as $[\mathrm{M}+\mathrm{H}]^{+}$with high intensities. The observed mass of the pyrazoline compounds has a small margin of theoretical value of expected compounds which confirmed the formation of $3,4,5$ and 6 pyrazoline compounds.

\section{Biological Evaluation}

The synthesized compounds were evaluated for their biological activities which included toxicity and antioxidant activities. The toxicity of the compounds was determined by Brine Shrimp Lethality Test method, while antioxidant activities were determined using DPPH radical scavenging assay method.

Among all the synthesized compounds, chalcone 2 was the only compound showed high toxicity, whereas four pyrazolines showed low toxicity (Table 1). Based on the literature, the crude extract can be categorized as toxic if it has a small $\mathrm{LC}_{50}$ value of $1000 \mu \mathrm{g} / \mathrm{mL}$ whereas for pure compounds, the compound is considered toxic when a small $\mathrm{LC}_{50}$ value of $200 \mu \mathrm{g} / \mathrm{mL}$ [14]. Chalcones 1 and 2 were considerably toxic with $\mathrm{LC}_{50} 11.47 \mu \mathrm{g} / \mathrm{mL}$ and 0.97 $\mu \mathrm{g} / \mathrm{mL}$ respectively. However, four pyrazolines were not considered as toxic compounds where pyrazoline 3 and 5 were slightly toxic with $\mathrm{LC}_{50} 105.7$ and $288 \mu \mathrm{g} / \mathrm{mL}$ respectively. Whereas pyrazoline $\mathbf{4}$ and $\mathbf{6}$ were considered nontoxic with $\mathrm{LC}_{50}>1000 \mu \mathrm{g} / \mathrm{mL}$.

Toxic properties of compounds $\mathbf{1}$ and $\mathbf{2}$ are thought to be due to the presence of groups $\alpha, \beta$ unsaturated ketone and substituent groups which are bound to the aromatic ring [6]. The presence of the methoxy substituent at the position of the aromatic ring acts as an electron driving group (mesomeric effect) which decreases the electrophilicity of the carbonyl group of the chalcones so that the affinity of the compound with the compound $\mathbf{1}$ and $\mathbf{2}$ receptor is greater [19].

The toxicity of pyrazoline compounds is influenced by heterocyclic pyrazoline rings and substituent groups which are bound to the phenyl ring. The methoxy substituents that are bound to the phenyl ring also have a positive mesomeric $\left(\mathrm{M}^{+}\right)$due to the presence of free electron pairs of oxygen atoms. The positive mesomeric effect only reaches the heterocyclic ring thus increasing electron density in heterocyclic rings, but the presence of a phenyl ring attached to the $\mathrm{N} 1$ atom can decrease electron density around the NN bond in the pyrazoline ring due to the pull of the resonance effect of the phenyl ring. As a result, the binding affinity of compound $\mathbf{3}$ and $\mathbf{5}$ is lower.

The results of the antioxidant activity of the compounds are presented in Table 1. Pyrazoline showed 
Table 1. Toxicity and antioxidant activities of synthesized compounds

Compound

${ }^{\star} \mathrm{LC}_{50}<200 \mu \mathrm{g} / \mathrm{mL}$ is active toxicity [7]

${ }^{* *} \mathrm{IC}_{50}>100 \mu \mathrm{g} / \mathrm{mL}$ is not active antioxidant [1]

good antioxidant activity especially pyrazoline $\mathbf{6}$ with $\mathrm{IC}_{50}$ $4.47 \mu \mathrm{g} / \mathrm{mL}$ and was more active than ascorbic acid as standard with $\mathrm{IC}_{50} 6.66 \mu \mathrm{g} / \mathrm{mL}$. It might be due to the structure of the pyrazoline compounds which have $\mathrm{N}$ substituents in the pyrazoline ring which increases their biological activity. Antioxidant activity is influenced by polarity and type of substituent compounds [16]. Chalcone is polar; however, since chalcone was substituted with naphthalene, this makes the antioxidant activity of chalcones decrease and can even become inactive. In addition, the presence of a substituent in the methoxy group which is in the ortho position on the pyrazoline compound acts as an electron donating group which will give the proton to the DPPH radical further because the conjugation system will direct the resonance into the aromatic ring to the pyrazoline ring so that free radicals are stabilized.

\section{- CONCLUSION}

In this study, pyrazoline compounds were successfully synthesized from chalcone with reasonable yield. All the synthesized compound were screened for 
their toxicity and antioxidant activity. The result of the study showed compound $\mathbf{2}$ and $\mathbf{1}$ is a highly toxic compound with $\mathrm{LC}_{50} 0.97$ and $11.47 \mu \mathrm{g} / \mathrm{mL}$, respectively. The antioxidant activity test using DPPH method showed that compound 6 possessed high antioxidant activity with $\mathrm{IC}_{50}$ of $4.47 \mu \mathrm{g} / \mathrm{mL}$.

\section{- ACKNOWLEDGMENTS}

This research was supported by the Ministry of Research, Technology, and Higher Education Indonesia.

\section{- REFERENCES}

[1] Kendre, M.M., and Baseer, M.A., 2013, Synthesis and evaluation of some new pyrazoline derivatives as antimicrobial agents, Orient. J. Chem., 29 (1), 253256.

[2] Insuasty, B., Ramírez, J., Becerra, D., Echeverry, C., Quiroga, J., Abonia, R., Robledo, S.M., Vélez, I.D., Upegui, Y., Munoz, J.A., Ospina, V., Nogueras, M., and Cobo, J., 2015, An efficient synthesis of new caffeine-based chalcones, pyrazolines and pyrazolo [3,4-b][1,4]diazepines as potential antimalarial, antitrypanosomal and antileishmanial agents, Eur. J. Med. Chem., 93, 401-413.

[3] Kumar, N., Bhatnagar, A, and Dudhe, R., 2017, Synthesis of 3-(4, 5-dihydro-1-phenyl-5-substituted phenyl-1H-pyrazol-3-yl)-2H-chromen-2-one derivatives and evaluation of their anticancer activity, Arabian J. Chem., 10 (Suppl. 2), S2443S2452.

[4] Khalil, N.A., Ahmed, E.M., El-Nassan, H.B., Ahmed, O.K., and Al-Abd, A.M., 2012, Synthesis and biological evaluation of novel pyrazoline derivatives as anti-inflammatory and antioxidant agents, Arch. Pharmacal Res., 35 (6), 995-1002.

[5] Barsoum, F.F., Hosni, H.M., and Girgis, A.S., 2006, Novel bis(1-acyl-2-pyrazolines) of potential antiinflammatory and molluscicidal properties, Bioorg. Med. Chem., 14 (11), 3929-3937.

[6] Jadhav, S.Y., Shirame, S.P., Kulkarni, S.D., Patil, S.B., Pasale, S.K., and Bhosale, R.B., 2013, PEG mediated synthesis and pharmacological evaluation of some fluoro substituted pyrazoline derivatives as antiinflammatory and analgesic agents, Bioorg. Med. Chem. Lett., 23 (9), 2575-2578.

[7] Anderson, J.E., Goetz, C.M., McLaughlin, J.L., and Suffness, M., 1991, A blind comparison of simple bench-top bioassays and human tumor cell cytotoxicities as antitumor prescreens, Phytochem. Anal., 2 (3), 107-111.

[8] Karthikeyan, M.S., Holla, B.S., and Kumari, N.S., 2007, Synthesis and antimicrobial studies on novel chloro-fluorine containing hydroxy pyrazolines, Eur. J. Med. Chem., 42 (1), 30-36.

[9] Palaska, E., Erol, D., and Demirdamar, R., 1996, Synthesis and antidepressant activities of some 1,3,5-triphenyl-2-pyrazolines, Eur. J. Med. Chem., 31 (1), 43-47.

[10] Ahmad, A., Husain, A., Khan, S.A., Mujeeb, M., and Bhandari, A., 2016, Synthesis, antimicrobial and antitubercular activities of some novel pyrazoline derivatives, J. Saudi Chem. Soc., 20 (5), 577-584.

[11] Mamolo, M.G., Zampieri, D., Falagiani, V., Vio, L., and Banfi, E., 2003, Synthesis and antifungal activity of ( \pm )-1-(5-aryl-3-pyridin-2-yl-4,5dihydro-pyrazol-1-yl)-2-imidazol-1-yl-ethanone derivatives, Farmaco, 58 (4), 315-322.

[12] Molyneux, P., 2004, The use of the stable free radical diphenylpicrylhydrazyl (DPPH) for estimating antioxidant activity, Songklanakarin J. Sci. Technol., 26 (2), 211-219.

[13] Palaska, E., Aytemir, M., Uzbay, I.T., and Erol, D., 2001, Synthesis and antidepressant activities of some 3,5-diphenyl-2-pyrazolines, Eur. J. Med. Chem., 36 (6), 539-543.

[14] Abid, M., and Azam, A., 2005, 1- $N$-substituted thiocarbamoyl-3-phenyl-2-pyrazolines: Synthesis and in vitro antiamoebic activities, Eur. J. Med. Chem., 40 (9), 935-942.

[15] Abid, M., and Azam, A., 2006, Synthesis, characterization and antiamoebic activity of 1(thiazolo [4,5-b] quinoxaline-2-yl)-3-phenyl-2pyrazoline derivatives, Bioorg. Med. Chem. Lett., 16 (10), 2812-2816.

[16] Shaharyar, M., Siddiqui, A.A., Ali, M.A., Sriram, D., and Yogeeswari, P., 2006, Synthesis and in vitro 
antimycobacterial activity of $N^{1}$-nicotinoyl-3-(4'hydroxy-3'-methyl phenyl)-5-[(sub)phenyl]-2pyrazolines, Bioorg. Med. Chem. Lett., 16 (15), 39473949.

[17] Azarifar, D., and Ghasemnejad, H., 2003, Microwave-assisted synthesis of some 3,5-arylated 2pyrazolines, Molecules, 8 (8), 642-648.
[18] Lu, Y., Hendra, R., Oakley, A.J., and Keller, P.A., 2014, Efficient synthesis and antioxidant activity of coelenterazine analogues, Tetrahedron Lett., 55 (45), 6212-6215.

[19] Bhuiyan, M.M.H., Hossain, M.I., Mahmud, M.M., and Al-Amin, M., 2011, Microwave-assisted efficient synthesis of chalcones as probes for antimicrobial activities, J. Chem., 1 (1), 21-28. 